\title{
La gran batuda de Llorenç Villalonga: un estudi crític
}

\author{
MARIDÈs SOLER \\ Universität Trier \\ marides-s@gmx.de \\ Recibido: abril de 2012 Aceptado: junio de 2012
}

Resum: De tota l'extensa obra villalonguiana, la novel-la La gran batuda en representa un dels punts culminants per la seva crítica social, a vegades càustica, però també irònica i còmica, dels canvis decisius i irreversibles, que va viure la societat europea arran dels esdeveniments de maig del 68. L'autor descriu amb ironia i amenitat el final d'una època anquilosada i profetitza alhora amb molta clarividència l'inici d'una de nova, la qual caracteritzarà la segona meitat del segle XX. La novel-la forma part de la tetralogia del cicle de $L a$ Lulú/Flo la Vigne. Malgrat la seva importància amb motiu de l'impacte social i el seu valor literari, no ha estat mai filmada ni traduïda a altres idiomes -altrament del que va succeir amb Bearn-, per la qual cosa no és tan coneguda com les seves novel-les principals, tot i que cal considerar-la com una peça clau dins del món villalonguià.

Mots clau: Llorenç Villalonga, La gran batuda, Flo la Vigne, L’àngel rebel, La Lulú, Lulú regina, Baltasar Porcel, novel·la mallorquina s. XX.

Resumen: En la extensa obra villalonguiana, la novela La gran batuda representa uno de los puntos culminantes debido a su crítica social, a veces cáustica, pero también irónica y cómica, de los cambios decisivos e irreversibles, que vivió la sociedad europea a consecuencia de los sucesos de mayo del 68. El autor describe, con ironia y amenidad, el final de una época anquilosada a la vez que profetiza, con gran clarividencia, el inicio de una nueva, que caracterizará la segunda mitad del siglo XX. La novela forma parte de la tetralogía del ciclo de Lulú/Flo la Vigne. A pesar de su importancia debido a su impacto social y su valor literario, no ha sido nunca filmada ni traducida a otros idiomas -contrariamente a lo que sucedió con Bearn-, por lo que no goza de tanta popularidad como sus novelas principales, si bien se puede considerar como una pieza clave dentro del mundo villalonguiano.

Palabras clave: Llorenç Villalonga, La gran batuda, Flo la Vigne, El ángel rebelde, La Lulú, Lulú regina, Baltasar Porcel, novela mallorquina s. XX. 


\section{ANTECEDENTS: L’ÀNGEL REBEL / FLO LA VIGNE}

La gran batuda forma part de la tetralogia del cicle del Flo la Vigne. Alguns crítics solen anomenar-lo també de La Lulú (Vidal i Alcover 1980: 93). ${ }^{1} \mathrm{Al}$ meu parer és més encertat, però, designar-lo pel del Flo la Vigne, ja que aquest és l'únic personatge que apareix contínuament en totes quatre novel-les, mentre que La Lulú només és la protagonista de les dues darreres. L'àngel rebel (1961), la novel-la que enceta el cicle, va ser revisada i ampliada més tard per l'autor i va publicar-se en segona edició sota el títol de Flo la Vigne (1974). ${ }^{2}$ La gran batuda (1968) és la segona novel.la, a la qual seguiran La Lulú (1970) i La Lulú regi$n a$ (1972). Al final del cicle, el Flo, un noiet purità ple d'il-lusions i ganes de millorar el món, acabarà esdevenint un dictador sense escrúpols de cap mena amb ínfules de noblesa.

El Flo la Vigne serà el protagonista indiscutible i únic de L'àngel rebel, mentre que en la resta de les novel.les posteriors serà només un personatge entre d'altres. ${ }^{3}$ Com a contrapartida a Un estiu a Mallorca, L'àngel rebel o Flo la Vigne podria titular-se Un estiu a París, donat que el temps i l'espai de la narració transcorren a la capital del Sena exactament durant un estiu. L'autor/narrador posa un anunci al diari per demanar un secretari que l'acompanyi a un viatge a París. Es presenta el Flo la Vigne, el qual per descomptat no serà el seu nom veritable. D'antuvi, cal remarcar l'ambigüitat del sexe d'aquest personatge, la qual cosa vindrà recolzada pel fet que es presenta vestit d'esquiador, i això, junt amb el seu nom, es presta també a confusió. Els personatges bisexuals, com veurem més tard, sovintegen a l'obra de Villalonga (1897-1980). D'acord amb les explicacions del mateix Flo, provindrà de la Suïssa francesa, tot i que al final del cicle l'autor posarà en dubte aquest origen i insinuarà la possibilitat que vingui de Mallorca. El narrador el contracta sense esbrinar ben bé del tot si es tracta d'un noi o d'una noia. Més endavant ens assabentarem que és un noi de divuit anys, al qual Madame Dormand (un nom que ja denota la seva professió de pitonissa) l'anomenarà, per la seva actitud i manera de pensar, «l'àngel rebel».

Durant l'estada a París la relació entre ambdós personatges s'afermarà i a la seva manera entraran en un dialèg constructiu. L'autor accentuarà la dicotomia

1 G. Bordons, basant-se en J. Vidal i Alcover, també l'anomena de La Lulú, tot i que només hi inclou tres novel·les: La gran batuda, La Lulú i Lulú regina (Villalonga 1980: 10).

2 Després d'haver clos el cicle de La Lulú, l'editor Joan Sales va canviar el títol pel de Flo la Vigne molt més suggestiu (Villalonga 1984: 66-67). Cal observar que Flo la Vigne va ser ampliada en tres capítols (IV, VII, XLIII). Segons Vidal i Alcover: «Tracta del contrast entre el liberalisme, tolerant fins quasi a la amoralitat, d'un senyor, d'un senyor i el rigorós puritanisme d'un noi que contracta com a secretari» (1980: 191).

3 Com Villalonga va explicar a Ferrà-Ponç, B. Porcel (1937- ) va servir de model pel Flo la Vigne: «Quan vaig conèixer a Baltasar Porcel ell encara no havia escrit res. Era aleshores un al.lot molt innocent que havia publicat algun conte. [...] la nostra relació és la base de la novel·la L'àngel rebel.» (1983: 167-168). També el mateix Porcel parla d'aquesta amistat: «Segons l'estat de la nostra relació, la "passió oculta" que hi posava Villalonga, Flo és millor o pitjor, el tracta amb simpatia o fins i tot el ridiculitza, sempre atent a les meves vicissituds ideòlogiques, personals, literàries. Millor dit, tal com ell les coneixia i les jutjava.» (1987: 8-9). 
entre el narrador, vell conservador representant de la generació antiga aferrada a les velles tradicions, i el Flo la Vigne, jove exaltat, representant de la ideologia liberal moderna i revolucionari, però molt purità, influït per les teories de Sartre i de Teilhard de Chardin. Tanmateix, no cal oblidar que la personalitat de Villalonga presentava aquesta mateixa dicotomia, per la qual cosa en els dos personatges de L'àngel rebel, podria descobrir-se un desdoblament de la idiosincràsia del mateix autor. Una personalitat contradictòria, la qual ofereix alhora dues vessants, que en certa manera es complementen, si es té en compte l'època crucial en què Villalonga va viure. Una postura reaccionària i conservadora, però sempre oberta $\mathrm{i}$ interessada davant els nous corrents i tendències irrefrenables de la dècada dels anys seixanta. ${ }^{4}$

La relació entre ambdós personatges s'enfortirà al llarg dels mesos, tot i que no serà mai d'igual a igual, no tan sols per la diferència d'edat i la posició subalterna del Flo la Vigne, sinó que, per part de l'autor, es desenvoluparà una inclinació afectiva intensa envers el seu secretari fins a arribar a considerar-lo el desitjat fill que no té. El tema de la falta de descendència, basat en la biografia personal de l'autor, aflora adesiara a través de tota l'obra de Villalonga. No obstant això, serà a Flo la Vigne on el narrador ens farà participar de la seva desolació de no tenir fills, esdevenint així un element importat de la novel·la. ${ }^{5} \mathrm{Com}$ un leit motiv apareixerà d'una manera més insistent i més dramàtica fins a arribar a proposar-li d'adoptar-lo, cosa la qual el Flo declinarà per por de coartar la seva llibertat, menyspreant el profit personal que l'adopció li reportaria. El narrador, per la seva banda, no desaprofitarà cap ocasió per tal de fer creure que en realitat és el seu fill, la qual cosa produirà àdhuc alguns malentesos. Ja que no podrà ser el pare adoptiu, com seria el seu desig, procurarà ser-ho des d'un punt de vista literari, bo i aprofitant-se de les inclinacions literàries del Flo la Vigne. D'aquí que l'animarà a seguir la seva vocació i se sentirà honrat quan aquell li demana una col-laboració per a una revista que vol fundar.

4 El mateix Villalonga va expressar més d'una vegada la seva postura política contradictòria i ambigua: «La Falange com a ideologia no em deia res. Fins i tot em resultava antipàtica. Jo m'havia format en una època de liberalisme: la de Gabriel Alomar. La Falange, però, era la cosa més oposada als sentiments d'un liberal: era un totalitarisme fet de tòpics, ordres, consignes, frases fetes i desfilades teatrals. Els liberals èrem esperits crítics, dubitatius i socràtics. Però no vaig poder evitar l'afiliació a la Falange. M'hi vaig limitar a tasques d'assistència mèdica — per cert mai no vaig haver d'assistir a ningú-, a escriure algun article i donar xerrades radiofòniques, tot plegat amb cap entusiasme i motivat per les circumstàncies» (Ferrà-Ponç 1983: 148).

5 Un succés que va viure Villalonga amb Eva Tay junt amb el fet de no tenir descendència de la seva muller va marcar decisivament tota la seva obra: «La meva amistat amb Eva Tay dugué com a conseqüència un fet que m'afectà molt. Sobtadament, un dia em comunicà que es trobava embarassada. Li vaig dir que no es preocupàs, que en nèixer l'infant jo el reconeixeria i l'ajudaria. No li vaig parlar de casar-nos, perquè sabia que ella no acceptaria. [...] Un dia vaig anar a veure-la i la vaig trobar trista i deprimida. Havia avortat i el fetus era dins un recipient de vidre. La visió d'aquell ésser que semblava viu surant dins el líquid amb totes les característiques d'un infant minúscul em va fer una impressió terrible. Certament, ha estat per mi una frustació no haver tengut fill. I el record d'aquell fill perdut m'ha companyat sempre, A L'àngel rebel és un element important de la novel-la» (Ferrà-Ponç 1983: 162). 
L'acció transcorre d'una manera compacta i homogènia, però, com és característic en l'obra villalonguiana, el Flo la Vigne no escaparà tampoc a una mort violenta, la qual, com també hi succeeix sovint, quedarà sense aclarir. El nom veritable del Flo la Vigne serà revelat només al final, després que ambdós personatges s'han separat des de fa temps. En tornar de nou a París dos anys més tard, el narrador s'assabenta que un autor novell anomenat Louis Salève s'ha suïcidat per cridar l'atenció envers la seva primera novel-la. En llegir-la, el narrador trobarà el conte seu, que havia lliurat temps enrera al Flo la Vigne per a la seva revista, per la qual cosa dedueix,- - com més tard a La gran batuda veurem erròniament- que el jove autor finat és del seu antic secretari.

\section{LA GRAN BATUDA}

Villalonga va acabar Flo la Vigne amb el suposat suïcidi d'aquest. Aquesta incertesa va permetre-li de desmentir aquella notícia a La gran batuda i de «ressuscitar-lo». En aquest cas no es tractarà d'una veritable resurreció, molt a gust de l'autor, sinó merament d'un malentès quant a la identitat dels personatges. En realitat, Louis Salève, el poeta que s'havia suïcidat, no era el Flo. La tàctica de deixar en suspens la mort dels personatges sovinteja a Villalonga, la qual cosa li ofereix la possibilitat de tornar-los a fer aparèixer més tard sense forçar massa l'argument.

És important recordar la data en què La gran batuda va publicar-se per a comprendre el missatge de l'autor. L'any 1968 va marcar l'inici d'una nova època i en aquesta obra l'autor, amb una perspicàcia molt clarivident, es fa eco dels canvis importants i decisius de la societat d'aquell any. D'aquí que l'estructura de la novel-la serà completament diferent a la seva precedent. La novel-la s'inicia amb el capítol Les dues germanes, fins ara dos personatges inèdits en l'obra villalonguiana. Aviat, però, farà acte de presència el Flo la Vigne, el qual servirà de nexe per introduir la Lilí, la germana petita, en el món de la aristocràcia i i de l'alta burgesia francesa. Aquestes dues germanes mallorquines, grans, solteres i empobrides es dirigeixen a París per continuar allà el viatge cap a Nova York, on la Núria, la germana gran, vol treballar com a professora d'espanyol. La Lilí, mig beneita, l'acompanya. Aquesta, malgrat l'empobriment, continua gaudint d'una vida de senyoreta rica, mimada i ben agombolada per la seva germana gran, a la qual tiranitza amb els seus capricis. Veient-la tan desvalguda i innocent, la Núria procura protegir-la per tal que no se n'adoni del descens social que estan sofrint. La Lilí, de jove, havia estat embarassada pel xofer de la família. La criatura va nèixer morta per gran alleujament de la família, però no de la Lilí, la qual amb prou feines va capir de què es tractava.

L'autor reserva a les dues germanes, i també al lector, una sorpresa, la qual tindrà lloc mitjançant el trabucament inesperat de llurs destins com a símbol del capgirament dels valors morals i socials, que es vivien en aquells anys i que ja deixaven perfilar els que encara seguirien. De camí cap a París, el tren para a una petita estació. La Lilí, capriciosa, obliga la seva germana a baixar per comprar-li pastissos de nata. La parada és més curta del que es pensaven i el tren se'n va amb la Lilí a dins, sola, sense diners i sense saber exactament on anaven. Així 
es troba a París, sense mitjans ni empenta suficients per afrontar una nova vida. En aquesta situació desesperada, de la qual ella a penes se n'adona, troba un senyor amable que en aparença vol ajudar-la. Al final, però, encara li robarà les maletes, que era l'únic que posseïa.

En aquells moments tan crítics, Villalonga, com un Deus ex machina, decidirà fer-la rica i famosa, bo i aprofitant les tendències artístiques de l'època, contra les quals llançarà una crítica feroç. Per casualitat, la Lilí anirà a parar enmig del rodatge d'una pel-lícula, en la qual actuarà espontàniament sense ser-ne conscient. Encara que el director capta tot seguit que la dona no té gens ni mica de talent artístic, sabrà treure el màxim de profit de la seva beneiteria. D'antuvi, la contractarà per papers secundaris per a les properes pel-lícules. La trobada fortuïta de la Lilí i Flo la Vigne contribuirà que aquest la faci ascendir al cim de la fama mitjançant tota mena de mètodes publicitaris escandalosos. Per això, no dubtarà a conferir-li una falsa i ancestral genealogia noble castellana. Arribarà tan lluny per casar-se amb ella, seguit ben aviat d'un divorci espectacular, la qual cosa coronarà la popularitat de la Lilí, la qual, mentrestant, ha adoptat el nom artístic de la Gitana per resultar més exòtic i comercial. El Flo la Vigne no en tindrà prou de fer-la triomfar en el món del cel·luloide, sinó que la convencerà per tal que es dediqui a la pintura abstracta, posant-li només com a condició que caldrà que pinti un quadre per dia.

-Tot consisteix que pintis quadres abstractes, que fugis de les velles escoles, ja esgotades, i que t'articulis amb la pintura d'avui.

-És que no en sé. Ningú me n'ha ensenyat.

-T'equivoques. Tu tens el sentit del color i del ritme. Que no hagis passat per les acadèmies és un avantatge. Tots els bons artistes són autodidactes. No prenen lliçons: en donen (Villalonga 1993: 29).

Aquí l'autor aprofitarà l'ocasió per llançar fortes diatribes contra la pintura de la seva època sense perdonar ni Picasso mateix:

Picasso, sentint-s'hi i desitjant que no li diguessin vell, en lloc de pintar els bons quadres d'altre temps, pintava ara senyores que tenien l'ull dret dos dits més avall que l'esquerre; és a dir, que de vell passava altre cop a infant, sense esperances d'arribar ja a adult: infant definitiu, immobilitzat per a sempre (Villalonga 1993: 145).

Més endavant farà sortir un pintor de fama consagrada, Daniel des Racó ${ }^{\text {, on }}$ tornarà a atacar la pintura abstracta. Publicitat i escàndols seran la clau per a triomfar aprofitant-se del poder i difusió dels mitjans de comunicació. Aquest èxit indiscutible es basa en el fet que el públic no té criteri propi, per la qual cosa és manipulable: «Tenia també el talent de comprendre que la pintura figurativa

6 El mateix Villalonga va confessar que «el personatge Daniel des Racó simbolitza la beneitura pictòrica de Joan Miró. El procés d'abstracció i simplificació de la pintura ha duit al no-res» (Ferrà-Ponç 1983: 158). 
no és pintura, motiu pel qual no calia treballar els quadres, sinó els marxants i la bona o mala premsa, segons es miri» (Villalonga 1993: 87)

En aquesta novel-la el Flo la Vigne serà assassinat de veritat a mans del seu amic, el poeta francès oligofrènic Bob. ${ }^{7}$ Igual com altres personatges el Flo tornarà a protagonitzar les novel-les següents d'aquest cicle (La Lulú i Lulú regina).

Malgrat la sobtada mort del Flo la Vigne a mitjan novel-la, el qual, a més de ser l'exmarit de la Gitana, actuava també com a agent seu, aquesta no quedarà desemparada. D'antuvi, Madame Dormand, la pitonissa, ocuparà el buit deixat pel Flo la Vigne com a agent artístic i mitjançarà per tal que Tom, un artista de cinema mediocre, li faci d'acompanyant. Aquesta carrera, ascendent com un meteorit, assolirà el seu zenit amb la concessió del premi Norbèlia (llegeixi's Nobel) per un rei nòrdic, que vol jugar una passada irònica a les tendències anàrquiques de 1 'art modern. ${ }^{8}$

Per la seva banda, la Núria, la germana gran assenyada, vegetarà per París a la recerca de la Lilí. Per guanyar-se la vida, es col-locarà de cambrera. Malgrat que s'assabentarà per la premsa dels èxits i escàndols de la Gitana i àdhuc veurà alguna de les seves pel-lícules, no associarà mai la germana beneita amb aquella artista i pintora famosa. Aquest malentès vindrà recolzat pel fet de creure que la Lilí s'ha negat al Sena. En una de les recerques per trobar la germana, van notificar-li que havien trobat el cadàver d'una noia desconeguda ofegada i va anar a veure'l. Com estava tan desfigurat, no va poder reconèixerla, però va quedar convençuda que es tractava de la Lilí. La novel-la acabarà amb l'acme de la glòria de la Gitana, mentre la Núria serà reclosa en un manicomi. La moralitat de la novel-la reflectirà la paradoxa d'aquesta vida, on els beneïts i poc escrupulosos triomfaran i els assenyats i equilibrats se'ls tindrà per folls.

\section{TÒPICS COMUNS}

En conjunt, l'obra de Villalonga presenta un món homogeni, amb personatges als quals l'autor atorga una idiosincràsia típica i uns costums molt característics de cada un d'ells. Amb aquests personatges, que sovint seran protagonistes de diferents novel-les, es repeteixen també determinats tòpics, els quals, com un leit motiv obssessionant, afloraran al llarg de tota la seva obra.

7 De nou Villalonga aprofitarà aquest personatge per llançar crítiques contra els poetes moderns: «Igualment en el terreny de la poesia on, a força de purisme i metàfora, els poetes han acabat per ser il-legibles. Així alguns poemes de Bartomeu Fiol m'inspiraren la figura de Bob, el poeta oligofrènic que apareix a la novel-la» (Ferrà-Ponç 1983: 158).

8 «Norbèlia podria ser una caricatura dels països industrials avançats com Suècia o Noruega. El Premi Norbèlia és una òbvia caricatura del premi Nobel, que han obtengut autors molt dolents com Echegaray quan hi havia gent molt superior com Galdós o Clarín» (Ferrà-Ponç 1983: 158). 


\section{a) Viatges a París}

Si per als turistes estrangers Mallorca representa un paratge de llibertat, per als mallorquins, especialment per a Villalonga, ho serà París. ${ }^{9}$ Un viatge a la capital del Sena significarà sempre un símbol de llibertat i de progrés lluny dels codis culturals provincians i antiquats de la postguerra a l'illa: «Això a Mallorca no ho podria fer enmig del carrer. Viatjar dóna molta llibertat.» (Villalonga 1993: 103).

Aquesta reflexió provindrà de la marquesa de Pax, la qual es permet la llibertat de comprar i menjar una banana enmig del carrer, la qual cosa no hauria pogut fer mai a Mallorca. En una reunió social captarà encara més les diferències d'aquest ambient més obert i liberal, bo i acceptant-les, però, amb certes restriccions: «Tenia la vaga noció que allò que era pecat a la terra natal, no ho és tant a París — sobretot si un hi va per poc temps» (Villalonga 1993: 149).

Sense atrevir-se a pronunciar-ho en veu alta, una altra impressió de la marquesa de Pax serà: «Es per això que el turisme resulta immoral» (Villalonga 1993: 149). A La gran batuda, els senyors de Bearn, ressuscitats, tornaran a visitar París tal com ho havien fet anys enrera a Bearn i Maria Antònia de Bearn no es podrà reprimir de comentar: «Es viatjar, ... fa perdre es miraments i fins i tot sa vergonya» (Villalonga 1993: 143).

El motiu pel qual el Flo la Vigne i l'autor entren en contacte serà també a causa d'una anada a París, on el Flo sobretot tindrà camp per córrer i desenvolupar-se. Les convencions socials sòlides i estables de la societat mallorquina s'esquerdaran i es diluiran d'una manera manifesta a la festa de Mrs. Sullivan. Felip d'Armenteres, amb lucidesa cosmopolita, serà el que resumirà en poques paraules la societat parisina molt diferent de la mallorquina: «Oh, a París, somrigué el baró, aquestes coses no tenen avui gaire importància» (Villalonga 1993: 171).

\section{b) Ambigüitat sexual}

A l'Espanya franquista, l'homosexualitat era considerada una desviació sexual que arribava àdhuc a ser perseguida. Imbuïts per aquella ideologia, no cal dir que la postura de governs nòrdics, més tolerants i liberals, sobtava als habitants de l'illa, els quals s'hi trobaven constantment confrontats a través de les parelles homosexuals que pul·lulaven per Mallorca. La postura de Villalonga serà en certa manera ambigua $i$, conseqüientment, desdoblarà aquest tema en dues vessants contràries:

9 El viatge, que va fer amb la seva muller el 1949, va inspirar-li el Desbarat titulat Viatge a París en 1947. La data no és exacta. En realitat és el resum de les seves experiències de dos viatges que va fer-hi el 1949 i 1952 (Ferrà-Ponç 1983- 145;155). Aquest viatge tornarà a ser recordat a Bearn, on Don Toni i Maria Antònia fan un viatge a París, on Don Toni aprofita per viatjar amb un globus aerostàtic. 
1) envers els personatges andrògins, l'autor sembla mostrar certa simpatia fins a arribar a una tàcita admiració. Molts seran els personatges el sexe dels quals l'autor, d'antuvi, deixarà en suspens. Aquesta incertesa vindrà recolzada pels vestits $i$ els pentinats unisexuals de moda, per exemple de l'Andrea Víctrix o el Flo la Vigne.

2) davant de l'amor homosexual es mostrarà intransigent i l'atacará feroçment, bo i ridiculitzant-lo per no comprendre'l i considerar-lo de mal gust: «El vell liberal es sentia ara incomprensiu i llançà el periòdic» (Villalonga 1993: 99).

A La gran batuda apareixerà una parella d'homosexuals, uns personatges realment insòlits en l'època en què va escriure la novel-la. Aquests es presentaran a la festa de Mrs. Sullivan. Avançant-se al seu temps, s'havien pogut casar legalment $\mathrm{i}$ havien anat de viatge de noces a Mallorca:

Com en un joc de teatre, mentre el doctor s'esvania, comparegueren dos homes horrorosament lletjos, que es miraven als ulls i alçaven cada un una copa de xampany. [...] No es tractava simplement d'homosexuals, que d'això n'hi ha hagut sempre, sinó que la seva lletjor, el seu repugnant somriure, constituïen la més cínica befa de tot el que hi pugui haver de noble en els sentiments de la nostra espècie (Villalonga 1993: 178-179).

L'autor, lúcid i sensible, es doblegarà impotent davant canvis irrefrenables i irreversibles d'una nova època. Aquest inici servirà per denotar inequívocament la indiferència de Felip d'Armenteres, el qual com a representant de l'aristocràcia en decadència, en primera línia no li interessaran els problemes dels homosexuals, per tenir-ne prou ell de caire econòmic:

-Pensava en el seu palau que tal volta no resistiria les contribucions noves i s'hauria de vendre a pisets que congestionarien el vell barri i el farien inhabitable a causa del soroll i els seatons de llauna. No deixava de ser una llàstima. També ho era, evident-ment, que la dona actual s'anàs convertint en mascle (Villalonga 1993: 173/4).

Tanmateix, a La Lulú, escrita dos anys més tard en plena època postmaig 68, sembla que l'autor hagi acceptat l'homosexualitat davant del fet innegable de la seva existència. Aquí es limitarà a insinuar d'una manera molt objectiva i neutral la sospita que el propi rei Miquel II ho sigui, tot abstenent-se alhora de qualsevol crítica o ironia mordent:

-Et dic i et repeteixo que aquest rei és marieta.

Ell va fer un gest de resignació.

-I al capdavall, ¿què tindria de particular, avui que n'hi ha tants? (Villalonga 1993: 190). 


\section{c) Infantilisme innocu}

Al llarg de totes les novel-les de Villalonga abundaran personatges, sobretot femenins, que es caracteritzaran per la seva innocència ratllant gairebé la beneiteria. Totes aquestes protagonistes són dones de l'alta burgesia educades amb els antics codis socials, en els quals la dona es trobava ben agombolada dins les presons daurades d'una família benestant. Per a un autor mallorquí aquesta situació li cridarà tot seguit l'atenció en contrast amb les dones estrangeres independents i alliberades, les quals anaven a Mallorca de vacances, soles o com a amants, o s'hi instal-laven com a artistes.

La vida dolça i planera, a la qual estaven acostumades les dones mallorquines, s'estava esquerdant i es troba irreversiblement en vies d'extinció. Malgrat això les protagonistes no se n'adonaran, ja que tindran la sort de tenir algú al costat, que es preocupa d'elles i les agombola dins la vida idíl-lica d'oci. Una manera de tenir-les contentes serà la de donar-los contínuament dolços, gelats o caramels, segons el gust de cadascuna. Els dolços presenten la connotació d'un plaer innocent i fugisser. Aquest agombolament s'accentuarà i anirà tan lluny fins a arribar a posar-los el caramel desembolicat a la boca, per la qual cosa la protagonista només tindrà la feina de llepar-lo, tot posant en relleu llur situació desvalguda i inútil: «Flo comprengué que l'havia de calmar. ¿Un bes? ¿Un caramel? Optà per posar-li un caramel dins la boca i encertà» (Villalonga 1993: 35).

Aquesta acció es repetirà sovint a Bearn, ${ }^{10}$ a L'hereva de Dona Obdúlia i a Andrea Víctrix, les protagonistes de les quals gaudiran d'una vida dolça recolzada per tota classe de llepolies. Per descomptat, la Gitana serà una candidata ideal a llepar caramels. Adesiara ho farà com a passatemps o per celebrar els seus èxits o per endolcir el seus fracassos: «En quant a la Lilí, està comprovat que per aquells dies no li interessaven encara els homes, sinó els caramels i els pastissos de nata» (Villalonga 1993: 26).

\section{d) Morts violentes}

L'autor, com a artífex amb ínfules d'antic senyor feudal, s'atorgarà a cient el poder de determinar la vida i la mort dels seus personatges. I no tan sols s'acontenta amb crear i matar, sinó també arribarà al punt de fer-los ressuscitar. Darrere d'aquesta distorsió del temps diegètic sembla amagar-se el desig inconfessat d'eternitat o almenys de joventut perpètua. Protagonistes com Xima o Felip d'Armenteres apareixeran a La gran batuda rejovenits, però no don Toni de Bearn, personatge amb el qual l'autor se sentia més identificat, per no dir fins a considerar-lo un alter ego. A vegades l'autor ressuscitarà els personatges sense cap comentari, d'altres vegades es limitarà, senzillament, a explicar, amb

10 També a Bearn D. Toni posa contínuament caramels desembolicats a la boca de Maria Antònia. 
certa ironia, cap al final i de passada, que aquests personatges ja havien aparegut molt abans:

L'autor d'aquesta història consignarà en primer lloc la presència de la marquesa de Pax, de don Toni de Bearn i la seva muller, dona Maria Antònia, aquests dos darrers morts molts d'anys abans, però, és clar, tornats a ressuscitar (Villalonga 1993: 142).

El món aristocràtic de Villalonga es veurà sovint sotragat per morts violentes i truculentes (suïcidis, assassinats misteriosos). A Bearn s'acabarà quan $\mathrm{Na}$ Maria Antònia pren unes píndoles verinoses, pensant-se que són caramels, i mor. Tot seguit, Don Toni també les prendrà, conscientment, a fi de morir amb la seva dona. Paral-lelament, abans havien succeït altres morts estranyes, mai no aclarides del tot, per exemple les de Madó Coloma i la Xima. A Mort de Dama, com el títol mateix ja indica, hi haurà una defunció, tot i que en aquest cas es tractarà d'una octogenària que fina d'una mort normal i amb ella simbòlicament tota una època. A Mort de Dama tenen lloc tres enterraments (el marit de Dona Obdúlia, el del marquès de Collera i el de la mateixa protagonista). Tots tres competeixen en ser el més lluït. No cal dir que el del de Dona Obdúlia, el darrer, s'endurà la palma. La importància d'enterraments representatius el trobarem també en el de don Jordi Coromines a la novel·la següent, L'hereva de Dona Obdúlia.

També el cicle del Flo la Vigne es veurà aombrat per morts violentes, començant pel mateix protagonista. La primera vegada va tractar-se d'una confusió, però a La gran batuda serà mort pel seu amic, el qual anirà a parar a la presó. Més tard a La Lulú no tindrà més remei que fer-lo ressuscitar oficialment, per la qual cosa durà el sobrenom del «resucitao», sense entrar en més detalls sobre les circumstàncies en què va tornar al món dels vius. Aquesta tendència a morts violentes continuarà pesant sobre el destí del Flo. A La Lulú li vindrà just de no ser afusellat i, per fí, a La Lulú regina no s'escaparà de ser víctima d'un atemptat mitjançant el qual aquesta vegada la seva defunció serà definitiva.

Per evitar distorsionar massa el temps diegètic, l'autor preferirà recórrer a morts ambigües, ja sigui quant a la identitat verídica del personatge, com en el cas de la primera mort del Flo la Vigne o com el cadàver desfigurat de la noia negada al Sena. Les causes de la mort seran sovint també equívoques i indeterminades, per exemple en el cas de Sancerre, el trapecista, deixarà sense aclarir si es tracta de suïcidi o assassinat així com tampoc no s'esbrinarà mai si la mort de la Palmira va ser deguda a mort natural o a un homicidi. Aquesta ressuscitarà per a participar sense problemes en la festa final de La gran batu$d a$. En aquesta festa el César Lácar, protagonista de El misantrop, frustat de la situació dissortada de la seva vida actual, aprofitarà el soroll per acomiadar-se d'aquest món d'un tret de pistola, de la qual cosa ningú se n'adona. El seu suïcidi transcorrerà com un succès perifèric sense importància. La duquessa de Guermantes, que l'esperava per passar la vetllada amb ell, en veure que no compareix, s'acontentarà amb la companyia de la Gitana i del Tom. 
La Gitana tampoc escaparà de sofrir una fi tràgica. A la festa final, vindrà tard perquè haurà simulat un accident per tal de cridar l'atenció sobre la seva persona. Accident, que ningú se'l creurà, perquè la sang de les seves ferides serà massa evident que es tracta només de pintura. Més tard a La Lulú ens assabentarem que, poc després d'haver obtingut el premi Norbèlia, morirà de debó d'un accident de cotxe: un Mercedes, com l'autor especifica expressament. La Lilí, la Gitana, serà un personatge que no tornarà a ressuscitar, però, com veurem en les novel·les següents, La Lulú en serà una versió rejovenida.

\section{e) Manca de descèndencia}

Aquest tema aflorarà amb més o menys intensitat a tota l'obra de Villalonga. Tanmateix és a L'àngel rebel on l'autor desenvoluparà un sentiment més íntim i paternal envers el Flo la Vigne. Al llarg de la seva obra apareixeran sovint fills de pares desconeguts. L'autor deixa sempre en dubte de si es tracten de fills naturals de grans senyors, per exemple a Bearn insinua adesiara la possibilitat que el capellà Joan de Mayol sigui fill del senyor de Bearn o, a Lulú regina que el Hans ho sigui del duc Mistelbach.

Pel contrari, a La gran batuda s'haurà esvaït el desig de tenir descendència. Potser davant del món decadent, que preveu per a un futur immediat, s'ha afeblit fins a desaparèixer completament les seves ànsies de paternitat. Només una sola vegada, i encara de passada, hi al·ludirà sense insistir gaire en aquest tema ni tampoc sense gaire desolació: «Don Toni, vellíssim i sense descendència» (Villalonga 1993: 173).

A La Lulú, l'autor, resignat, presentarà la nova generació del jovent progressista, per al qual la descèndencia no té la importància que gaudia dins una societat feudal aferrada a la nissaga i a la terra. Des d'aquest nou angle de visió de l'amor, del matrimoni i de la família justificarà de retruc els matrimonis homosexuals: «-El després ja es veurà. Nosaltres no tenim futur, com no tenim fills» (Villalonga 1993: 204).

\section{LA GRAN BATUDA FINAL}

La gran batuda no és una novel-la homogènia i de narrativa lineal com L'àngel rebel. L'argument és bastant desllorigat i presenta certes reminiscències dels Desbarats. Consta de tres parts ben definides; la primera i la tercera són recloses en elles mateixes i no tenen res a veure entre elles, si no fos la segona que serveix de pont d'unió. El potencial narratiu del conte de Les dues germanes, amb què s'inicia la novel-la podria haver abastat tota una novel-la. No obstant això, el Flo la Vigne, personatge ja conegut, serveix de missatger i d'enllaç per anunciar la imminent presència de molts altres personatges del món villalonguià. Així trobarem el Toni de Bearn junt amb la seva dona i la marquesa de Pax, els quals seran convidats a la festa a través de Madame Dormand, una antiga amiga del Tonet. Allà veuran Dona Francisca, l'hereva de dona Obdúlia, la vista de la qual farà posar violents als mallorquins, indecisos si anar a saludar-la o esquivar- 
la: «-Jesús, Senyor, exclamà dona Maria Antònia. ¿Què dimonis deu haver vengut a fer aquí? Sols mancaria que s'assegués amb noltros. Per si al cas, convé no mirar-la» (Villalonga 1993: 163).

En aquesta festa aniran compareixent altres personatges, alguns dels quals seran meres aparicions o imaginacions, com per exemple la Xima o la Palmira, mortes temps enrera. L'autor deixarà en suspens si es tracta veritablement d'aparicions o imaginacions. Molts d'aquests personatges, ja coneguts d'altres novel-les, per exemple el Cèsar Làcar o el Joan Mayol, els trobarem afectats pels canvis socials que els ha fet anar a menys. El primer, que recordàvem com un jove fort $i$ atlètic, haurà acabat de pinxo $i$ es trobarà en una relació laboral equívoca amb la duquessa de Guermantes. Aquesta l'ha contractat com a xofer, tot i que en realitat no li'n calia cap perquè en tenia ja un. Cal recordar aquí també que a L'àngel rebel, el narrador contracta els serveis del Flo la Vigne com a secretari sense tampoc necessitar-lo. La duquessa de Guermantes tampoc escaparà a la decadència. La seva elegància proverbial haurà degenerat en anar ara vestida de mal gust, la qual cosa farà comentar a Maria Antònia de Bearn: «-Jesús, Senyor ..., exclamà na Maria Antònia, ¿i és possible que això sigui sa duquessa de Guermantes? Va vestida de bandera portuguesa» (Villalonga 1993: 144). Tampoc el Joan Mayol, antic secretari de Toni de Bearn i suposat fill natural d'aquest, haurà escapat a un destí decadent. Poc després de la mort dels senyors de Bearn, va sortir de capellà i sense mitjans econòmics va quedar completament arruïnat no tenint més remei de treballar en un orquestrina i donar lliçons a un gimnàs, on va conèixer el Cèsar.

Com un compositor, el qual al final d'una simfonia recorre a tota la instrumentació de l'orquestra, en el darrer capítol «La gran batuda final»Villalonga passarà revista i comptes, a través de tota la galeria dels seus personatges preferits, als canvis que succeïen en aquells anys crucials, en què tots els valors tradicionals s'estaven trabucant. El zenit d'aquesta època de transició coneixerà el seu punt culminant en el maig del 68. Impotent per detenir tot aquell allau de canvis, Villalonga claudicarà i no perdrà el temps per presentar-hi més resistència, sinó que ell mateix s'alinearà amb ironia al costat dels nous temps i àdhuc sovint s'avançarà a aquestes ideologies revolucionàries amb una postura força ambigua. Per descomptat, no arribarà a ser-ne mai un cabdill defensor, però amb molta lucidesa acceptarà la nova societat, amb humor, com a irreversible i irrefrenable. Així, a través de Toni de Bearn, ens farà conèixer la seva postura: «A don Toni, veure tanta de gent coneguda a una festa tan esburbada, el feia meditar» (Villalonga 1993: 179).

Tots els personatges mallorquins aplegats en aquell saló, a Mallorca ni s'haurien saludat i menys encara enraonat entre ells. Ara, a París, seran testimonis estupefactes del triomf de la Gitana i de la decadència de la duquessa de Guermantes. Per la seva banda, no tindran més remei que acceptar la seva derrota. A través d'aquest públic internacional amb gran representació mallorquina, l'autor posarà en evidència la confrontació palesa de les antigues i noves ideologies socials. El microcosmos de la burgesia mallorquina s'enfonsarà irremeiablement davant del giravolt total de la societat fent pas a les noves generacions representades per la Gitana o per personatges marginats com el matrimoni d'homosexuals. 
Al final de la festa la duquessa convidarà la Gitana i el Tom a la seva taula, una acció que servirà per denotar el zenit del desgavell i trabucament complet de totes les convencions socials regnants fins aquell moment. I com a colofó a aquests desordres, la novel-la es clourà amb la concessió del premi Norbèlia a la Gitana. Malgrat l'oposició dels ministres, el rei Miquel II (portaveu de Villalonga) s'alinearà als temps moderns dominats per la demagògia:

-Temps nous, vida nova, senyor ministre. Vivim sota «l'amable imperi de les masses», com ha dit justament un il·lustre col·lega seu. [...] la meva cosina Elisabeth d'Anglaterra [...] condecorà no fa gaire un conjunt musical d'escambuixats atenent-se a les indicacions dels secretaris laboristes. ¿A vosté li agraden els Beatles, senyor ministre? (Villalonga 1993: 188/9).

Pintura, música, pel-lícules, ideologia, amor, convencions socials, tots aquests seran els temes principals, contra els quals Villalonga apuntarà com a blanc dels seus comentaris irònics. Amb gran perspicàcia l'autor reconeixerà com inevitable l'encetament d'una nova era i alhora l'acceptarà amb resignació i en part amb cert humor sarcàstic.

\section{RECEPCIÓ}

La gran batuda s'alinea amb la tradició de les novel·les problemàtiques de Villalonga. En aquesta tradició ja l'havien precedit Mort de dama i Bearn. ${ }^{11}$ Totes elles van provocar grans polèmiques entre els crítics. El motiu d'aquestes reaccions virulentes rau en el fet que, sense deixar-se acoquinar per la crítica ni àdhuc pel mateix editor, l'autor tocava amb encert temes conflictius que caracteritzaven la societat de l'època.

El missatge de Villalonga és clar i unívoc: Mort de dama va servir de pretext per a tipificar la societat mallorquina en franca decadència, ${ }^{12} \mathrm{i}$ va indignar als mallorquins, perquè molts d'ells es veien retratats en aquells personatges esperpèntics i ridículs, Bearn va sobtar perquè posava en evidència la decadència irrefrenable del món idíl-lic dels senyors rurals i a La gran batuda la seva crítica anirà més lluny i s'avançarà per introduir amb ironia distant la generació del maig del 68, on els principis d'absurditat, mal gust i efimeritat hi dominaran:

11 En una carta a Jaume Pomar del 29 de setembre de 1969 Villalonga comenta: «Li he fet observar, a Barral, que La gran batuda ve a ser la Mort de Dama d'avui, una sàtira contra la societat actual, així com Mort de Dama ho fou contra la dels anys vint. Sales no volgué encaixar aquesta sàtira per no malparlar contra la gent d'ara (¿por?) i en canvi admira Mort de Dama perquè els anys vint estan ben morts. Jo crec que seria més noble i oportú combatir l'estupidesa d'avui (falsos valors, Lilís buides, princeses cineastes, poesies abstractes, sense cap contengut, duquesses lloros, Premis Nobels, etc.)» (Villalonga 1984: 38).

12 «Vaig escriure La gran batuda durant l'estiu del 1967, a Binissalem. Amb aquesta novel·la vaig voler fer la Mort de dama d'avui. però no d'una classe social, ni d'un petit món com Mallorca, sinó de la societat del món actual. Conté elements que poden semblar caricatures però que són ben certs. El poemet beneit de les mans que tenen cinc dits es publicà a Ínsula i record que agradava molt a Jaume Vidal Alcover» ( Ferrà-Ponç 1983: 157). 
-Això, aquesta espècie de gran batuda final, no serà la fi del món, senyora?

Madame Dormant s'ho prengué, o fingí que s'ho prenia, com un compliment.

-Ho sembla, estimat senyor. Aquest homenatge ha resultat esplèndid. Mrs. Sullivan sap fer les coses bé. No és la fi del món, però és una fi de festa apoteòsica (Villalonga 1993: 180).

Igual que les novel-les precedents, La gran batuda és una novel-la de decadència, en la qual l'autor passa comptes als codis socials antiquats, molts d'ells procedents del segle XIX, però que encara eran vàlids a mitjans del segle XX. Villalonga els anorrearà a contra-cor i alhora ridiculitzarà els nous. Davant d'aquella època de transició la seva postura és ambigua. En el fons, es tracta d'un escriptor inconformista en eterna contradicció entre una actitud liberal i progressista per una banda, i conservadora i reaccionària per l'altra. Villalonga és i roman el que a ell li agradava ser i es definia: un volterià del segle XX.

L'escenari narratiu de La gran batuda traspassarà els límits reduïts de l'illa balear per situar-se a París, la capital cosmopolita més important d'aquella època, la qual va ser escenari dels succesos més decisius del maig del 68. D’allà va sorgir la revolució social que caracteritzarà el desenvolupament de la segona meitat del segle XX. Des de diferents perspectives La gran batuda retratarà amb gran exactitud i perspicàcia aquell moment de transició. ${ }^{13}$

Considerant ara amb la distància deguda al pas del temps les crítiques polèmiques, que va suscitar en la seva època, aquestes ens semblen puerils $i$ provincianes a penes comprensibles per a un lector de començaments del segle XXI. Totes tres novel-les (Mort de dama, Bearn, La gran batuda) caracteritzen èpoques determinades de transició i romanen com a testimonis valuosos del procés irreversible dels canvis socials, que van succeir en cada una d'elles. El temps ha donat la raó a Villalonga, bo i ridiculitzant els seus detractors. Els temes, que escandalitzaren els lectors conservadors dels anys seixanta, han esdevingut una realitat completament normal. En l'actualitat són acceptats sense discusió, àdhuc pels més carques. Vidal i Alcover dóna una visió de la recepció plena d'animositat de La gran batuda en un article que va conèixer també, igual com la novel·la, grans vicissituds per ser publicat: ${ }^{14}$

13 «Bajo motivaciones diferentes, la historia se repite: una de las últimas novelas de L.V., La gran batuda, ha indignado a los progresistas como Mort de dama indignara antaño a los conservadores. Parte de sus lectores actuales hubieran preferido acaso que el autor se immovilizara en una posición definitiva así como Aina Cohen escribía eternamente poesías a La Camperola y a los almendros floridos. Cabe empero pensar que L.V. es siempre más inconformista que retrógrado, puesto que no admite que el pasado haya sido mucho mejor que el presente y afirma, casi dogmáticamente, que los paraísos sólo son verdaderos cuando ya no existen» (Villalonga 1984: 23).

14 Vidal i Alcover explica en una nota les dificultats que va tenir per publicar el seu article: «Aquest article era destinat al setmanari Tele/estel. El varen retenir durant molt de temps, fins que en demanar-los jo explicacions, digueren que es negaven rodonament a publicar-lo. El director Avel-lí Artís, més conegut per «Sempronio», em va aconsellar que escrivís cròniques de festes populars. La gran batuda va desenganyar, d'una vegada per sempre, els qui havien cregut en el progressisme de Llorenç Villalonga» (Vidal i Alcover 1980: 181). 
La gran batuda, és a dir l'apoteosi final, no ha estat precisament la novel.la que en porta el nom, sinó, la polèmica subsegüent. Sembla que Llorenç Villalonga - tan assenyat $\mathrm{i}$ encastat en les ortodòxies del més rigorós tradicionalismedesencadena, cada vegada que escriu una tempesta de disconformitats (Vidal i Alcover 1980: 181).

No tan sols no va ser acceptada per la crítica, sinó tampoc no va agradar a l'editor, Joan Sales:

Ara li toca a la darrera novel-la de moure enrenou. La discrepància s'ha produït -i el cas no és insòlit— entre autor i editor. [...] Tots dos són liberals —Villalonga confessa expressament que s'ha format dins l'època liberal-i tots dos, mútuament, es respecten: Sales editant el llibre i Villalonga permetent a Sales que hi posi una nota en cap on exposa les seves discrepàncies (Vidal i Alcover 1980: 183).

Vidal i Alcover va ser un dels pocs crítics que amb gran perspicàcia va saber reconèixer el valor testimonial de la novel-la. Segons ell és una de les poques obres divertides del món villalonguià, tot i que el propi autor la considerava pessimista:

Jo no la trob, ni de molt, «la novel-la menys afortunada de Llorenç Villalonga», sinó un llibre molt reeixit i ben contat, [...] Això sí, que és una novel-la-testimoni [...] La gran batuda és un dels llibres veritablement divertits de Villalonga, comparable, per la intenció i el to, a Mort de dama o als Desbarats: una novel-la aguda, graciosa, àgil, desllorigada fins a l'esperpent i contrapesada, alhora aquesta amenitat de vie en rose, per una tràgica feixugor que tomba sobre l'antagonista de la novel·la (Vidal i Alcover 1980: 185).

Per la meva part, no diria que es pugui afirmar que La gran batuda sigui una novel-la divertida, ja que, llevat d'alguna escena còmica, es percep l'atac feroç $\mathrm{i}$ implacable de l'autor contra tots el que han col-laborat en el trabucament de la ideologia fins ara dominant. Els personatges seran esperpèntics capgirant-se com marionetes segons el caprici de l'autor. El desenllaç i destí de molts d'ells serà tràgic i la nota dominant al llarg de tota la novel·la anirà d'una fina ironia passant per un sarcasme punyent amb pinzellades adesiara grotesques fins a arribar a una franca impotència i resignació.

\section{LES NOVEL·LES DE LA LULÚ}

La Lulú i Lulú regina són les dues darreres novel-les del cicle del Flo la Vigne. La primera duu el subtítol La princesa que somreia a totes les conjuntures, amb el qual denota d'antuvi una de les qualitats principals de les protagonistes: la seva innocència pueril $\mathrm{i}$, en el fons, una capacitat innata per adaptar-se a totes les circumstàncies. La Lulú és la resposta de Villalonga a un plagi que li havia fet Mercè Rodoreda (1909 - 1983) d'un capítol de Bearn. Com a contrapartida, l'autor mallorquí farà sortir de passada alguns personatges de La plaça del Diamant i de El carrer de les camèlies. L'argument de les novel-les de La 
Lulú serà distorsionat $\mathrm{i}$ els personatges encara més esperpèntics que les novel-les anteriors. Com anunci del seu futur reial i com a interrelació de realitat i ficció, el Flo la Vigne ja compareixerà la primera vegada disfressat de rei de cartes.

Les novel-les posteriors a La gran batuda es desenvolupen de ple en la nova era desgavellada. Els protagonistes principals seran el Flo, el «resucitao», i La Lulú, la qual encara que de fet no és cap ressuscitada, s'hi identificarà a primera vista com a una reencarnació de la Lilí. L'única i gran diferència entre ambdues protagonistes radicarà en el fet que La Lulú serà jove, bellíssima i hospiciana. Pel contrari, la Lilí passava dels quaranta, pesava prop de vuitanta quilos i venia de bona família. Com la seva predecessora, també serà innocent ratllant sovint a la beneiteria. No lleparà caramels, sinó que continuarà delint-se pels gelats de nata.

La Lulú i el Flo es coneixeran al principi de la novel-la, però aviat llurs camins se separaran. Per la seva gran bellesa La Lulú gaudirà d'un gran ascens social, molt més alt que la Lilí, ja que arribarà a casar-se amb Mateu, un príncep austríac. Mentrestant el Flo també haurà fet carrera i haurà anat a parar com a conseller de Miquel II a Nordland, personatge, que ja havia aparegut a La gran batuda. Amb motiu d'un cop d'estat serà assassinat per un dels seus generals i el Flo haurà d'escapar per no ser afusellat.

La Lulú regina començarà amb el casament de La Lulú amb el Mateu amb gran disgust de la parentela noble d'aquest. El Flo es trobarà a Dinamarca al front d'un grup revolucionari, que lluita per a combatre la tirania del dictador de Nordland, succesor del rei Miquel II. Els destins de La Lulú i del Flo, a primera vista distanciats, s'aniran apropant mitjançant una correspondència, la qual al llarg de la novel-la s'anirà intensificant i intimant. Amb ajuda dels marginats revolucionaris el Flo aconsegueix per fi enderrocar el dictador i fer-se amb el poder de Nordland. Un cop assolit aquest, aviat s'oblidarà de les seves teories anarcosocialistes i aspirarà a ser nomenat rei. Per això, no dubtarà a fer metrallar els marginats que l'havien ajudat. La filosofia del peix que es mossega la cua, emblema de L'ángel rebel, clourà així el seu cercle. ${ }^{15}$

Quan el príncep Mateu, marit de La Lulú, és assassinat, en unes circumstàncies misterioses que no s'arribaran a aclarir mai, és natural que el Flo demani a la Lulú el matrimoni. Aquesta, ja vídua, accepta i va a Nordland. El casament es fixa per al matí del mateix dia de la coronació, la qual tindrà lloc al vespre: «La dinastia dels dos quarts d'hora», com Villalonga l'anomenarà irònicament, ja que mitja hora més tard de ser coronat rei, el Flo la Vigne serà víctima d'un atemptat, l'autor del qual no s'arribarà a esbrinar mai (Villalonga 1982: 208).

La Lulú se salvarà d'aquest atemptat i a l'epíleg la trobarem com una vella octogenària, rica i piadosa, dedicada a obres de caritat. Com un conte de fades, bastant insòlit a l'obra de Villalonga, la pobra hospiciana, bella i poc intel-ligent, símbol de la nova generació, acabarà com una gran senyora, respectada i ben

${ }^{15}$ En el colofó de la primera edició de L'àngel rebel hi figurava com a símbol d'aquesta filosofia una vinyeta de Pau Fornès, que mostrava un lluç que es mossega la cua i a les Obres completes (1998) es reprodueix la mateixa vinyeta a la portada. 
considerada per tothom. De retruc, Villalonga acceptarà també a desgrat aquest trabucament com un desenvolupament ineludible i irreversible típic de la nova era.

\section{BIBLIOGRAFIA}

Broch, À. (1985) Literatura catalana. Balanç de futur, Barcelona, Edicions del Mall.

Ferrà-Ponç, D. (ed.) (1975) Cultura i política a Mallorca, 1, Randa, 2 (vol. monogràfic).

Ferrà-Ponç, D. (ed.) (1976) Cultura i política a Mallorca, 3, Randa, 4 (vol. monogràfic).

Ferrà-Ponç, D. (ed.) (1978) Cultura i política a Mallorca, 5, Randa, 7 (vol. monogràfic).

Ferrà-Ponç, D. (1983) "Notes autobiogràfiques de Llorenç Villalonga", Randa, 15, pp.131-168.

Hösle, J. (1979) “Zur Literatur Mallorcas”, Iberoromania, 9, pp. 122-135.

Johnson, P. L. (2002) La tafanera posteritat, assaigs sobre Llorenç Villalonga, Barcelona, Publicacions de l'Abadia de Montserrat.

Llompart, J. M. (1964) La literatura moderna a les Balears, Mallorca, Moll.

Moles, J. + Gallofré, J. (eds.) (1993-1994) Vida i obra de Llorenç Villalonga, 1, 2, Randa, 33/34, Barcelona: Curial.

Perelló i Comas, Aina (1993-1994) «Déus, herois, persones i personatges en "L’àngel rebel"», Moles, Joaquim + Gallofré, Josepa (eds.), Vida i obra de Llorenç Villalonga, Barcelona, Curial, pp. 35-54.

Pomar, J. (ed.) (1987) "Segona aportació a l'epistolari de Llorenç Villalonga", Randa, 22, pp. 129-137.

Pomar, J. (1984) Llorenç Villalonga. Discurs amb motiu de la seva proclamació com a fill il.lustre de Palma, Palma, Ajuntament de Palma.

Pomar, J. (1995) El meu Llorenç Villalonga, Palma, Moll.

Pomar, J. (2001) A la recerca de Llorenç Villalonga, Palma, El tall.

Pomar, J. (2003) La obra de Llorenc Villalonga: estudios y ediciones (19952001), Berlín, Ibero-Amerikanisches Institut PK.

Riquer, M. de + Comas, A. + Molas, J. (eds.) (1988) Història de la literatura catalana, 11, Barcelona, Ariel, pp. 119-156.

Rosselló Bover, P. (ed.) (1999) Actes del Col-loqui Llorenç Villalonga, celebrat a Palma del 20 al 22 de novermbre de 1997, Barcelona, Publicacions de l'Abadia de Montserrat. 
Rosselló Bover, P. (2001) Els paradisos perduts de Llorenç Villalonga, Barcelona, Proa.

Simbor Roig, V. (1999) Llorenç Villalonga a la recerca de la novel-la inefable, Barcelona, Publicacions de l'Abadia de Montserrat.

Soler, M. (1989) "Una fi entre daurats i púrpures: Semiologia de la decadència a 'Mort de dama' de Llorenç Villalonga', Estudis de llengua i literatura catalanes, 19, Miscel-lània Joan Bastardes, Barcelona, Publicacions de l'Abadia de Montserrat, pp. 265-283.

Soler, M. (1990) "Les imatges estètiques -verbals i visuals- en el drama, en la novel-la i en el film de Bearn", Miscel-lània Joan Fuster, estudis de llengua i literatura, 2, Barcelona, Publicacions de l'Abadia de Montserrat, pp. 271287.

Soler, M. (2006) "Els signes no verbals de l'emoció a la novel·la i al film de "Bearn" de Llorenç Villalonga», Miscel-lània Jordi Carbonell, Randa, 56, Barcelona, Publicacions de l'Abadia de Montserrat, 75-90.

Vidal i Alcover, J. (1980) Llorenç Villalonga i la seva obra, Barcelona, Curial.

Vidal i Alcover, J. (1984) Llorenç Villalonga (o la imaginació raonable), Palma, Ajuntament.

Villalonga, Ll. (1956) Bearn o la sala de las muñecas. Prólogo parabólico de C. J. Cela. Dos notas previas del autor, sin firmar. Viñeta de P. Fornès. Palma, Atlante.

Villalonga, Ll. (1961) L'àngel rebel, Palma, Moll.

Villalonga, Ll. (1969) El ángel rebelde. Prólogo y versión de J. Pomar. Ed. bilingüe català-castellà. Barcelona: Polígrafa.

Villalonga, Ll. (1972) La Lulú, pròleg de J. Sales, Barcelona, Club Editor.

Villalonga, L. (1974) Flo la Vigne, amb "Notícia de Llorenç Villalonga" per D. Ferrà-Ponç, 2ona versió ampliada i revisada de L'àngel rebel, Barcelona, Club Editor.

Villalonga, Ll. (1980) Juliette Récamier i altres narracions, a cura de G. Bordons. Barcelona, Edicions 62.

Villalonga, Ll. (1981) L'hereva de dona Obdúlia o Les temptacions. Barcelona, Club Editor.

Villalonga, Ll. (1982) Lulú regina o La princesa que somreia a totes les conjuntures. Barcelona, Club Editor.

Villalonga, Ll. (1984) Primera aportació a l'epistolari de Llorenç Villalonga. Transcripció i anotació de J. Pomar, pròleg de J. Zaforteza Calvet, Palma, Antiga Impremta Soler.

Villalonga, Ll. (1985) Bearn o la sala de las muñecas, a cura de J. Vidal i Alcover, Madrid, Cátedra. 
Villalonga, Ll. (1985) Muerte de dama. La heredera de Doña Obdulia o las tentaciones, trad. de J. Vidal i Alcover, Barcelona, Plaza \& Janés.

Villalonga, Ll. (1987) Els meus inèdits de Llorenç Villalonga, edición de B. Porcel, Barcelona, Edicions 62.

Villalonga, Ll. (1988) La heredera de Doña Obdulia, Barcelona, Mondadori España.

Villalonga, Ll. (1988) Mort de dama, Barcelona, Club Editor.

Villalonga, L1. (1988 -1998) Obres completes, ed. Josep A. Grimalt, 1-3, Barcelona, Edicions 62.

Villalonga, Ll. (1993) La gran batuda, amb una nota de J. Sales i un pròleg de l'autor, Barcelona, Club Editor.

Villalonga, M. (1983) Autobiografia, Madrid, Trieste.

Wagner, B. (1988) "Mallorca und die Universalität der Lumières: 'Bearn o la sala de les nines' von Llorenç Villalonga”, Zeitschrift für Katalanistik, 1, pp. $52-61$ 
